\title{
Effect of Chemicals and Bio-Inoculants on Seedling Growth and Vigour of TNAU Papaya CO.8 (Carica papaya L.)
}

\author{
Donaka Dayeswari $^{\text {** }}$, Jone Auxcilia ${ }^{1}$, K. Malarkodi ${ }^{2}$ and R.M. Vijayakumar ${ }^{1}$ \\ ${ }^{1}$ Department of Fruit Crops, ${ }^{2}$ Department of Seed Science and technology, Horticultural \\ College and Research Institute, Tamil Nadu Agricultural University, Coimbatore, India
}

*Corresponding author

\section{A B S T R A C T}

\begin{tabular}{|l|}
\hline K e y w o r d s \\
$\begin{array}{l}\text { Chemicals, } \mathrm{Bio}^{-} \\
\text {inoculants, } \mathrm{KH}_{2} \mathrm{PO}_{4}, \\
\text { papaya, } \mathrm{PPFM}_{\text {, Seedling }} \\
\text { growth and vigour }\end{array}$ \\
\hline Article Info \\
\hline $\begin{array}{l}\text { Accepted: } \\
\text { 24 February } 2018 \\
\text { Available Online: } \\
10 \text { March } 2018\end{array}$ \\
\hline
\end{tabular}

\section{Introduction}

Papaya (Carica papaya L.) is rapidly growing, perennial herbaceous plant. It is dicotyledonous, polygamous diploid species with a small genome of $372 \mathrm{Mbp} / 1 \mathrm{C}$ (Arumuganathan and Earle, 1991) having nine pairs of chromosomes (Bennett and Leitch, 2005 ) and was introduced to India in the $16^{\text {th }}$ century. It is one of the most important fruit crops belongs to the family Caricaceae grown in tropical to subtropical areas all over the world and is mainly propagated by seeds which show wide variability in germination and seedling growth. It has long been grown primarily for its delicious fruits which are the rich source of carbohydrate, minerals, vitamin
A, and ascorbic acid. The fruits can be used in the preparation of products like jam, jelly, tuty-fruity, marmalade, nectar, wines, syrup, dehydrated flakes and baby foods. The digestive enzyme papain, obtained from latex is an industrial ingredient used in pharmaceuticals, brewery, meat, dairy, textile, photographic, optical, tanning, cosmetic, detergent, food and leather industries and so there is a growing demand for the papain. Papaya is a short duration fruit crop, owing to its high productivity and high returns, it is becoming very popular with many growers (Chattopadhyay, 2003). India is the largest producer of papaya covering an area of 1.15 lakh ha, producing 49.12 lakh tonnes/ ha Anon (2015). 
The significant role of chemical treatment through $\mathrm{KNO}_{3}$, and gibberellic acid in relation to breaking dormancy, seed germination, growth and development of plant has been observed Kadam (1992). Seedlings are raised in the nursery before transplanting to the main field. However, poor germination of seeds and high mortality rate of papaya seedlings after transplanting restrict the availability of healthy planting material Barche et al., (2010).

Healthy seedlings are the pre-requisite for healthy plants in the field to reap the potential yield. Seedling vigour is affected by many factors like seed quality and type of substrate used, environmental factors etc. Some of the problems faced by papaya growers are slow, erratic growth of papaya and high initial seedling mortality. Thus, producing healthier and quality of seedlings obtained from a nursery influences re-establishment in the field and the eventual productivity of an orchard. Plant vigour depends on the seedling vigour. Hence attention has to be given from nursery stage itself in order to improve the seedling vigour.

\section{Materials and Methods}

The experiment was conducted at the nursery, University Orchard, Department of Fruit Crops, Horticultural College and Research Institute, Tamil Nadu Agricultural University, Coimbatore during 2015-2016. The chemicals and bio-inoculants were obtained from chemicals and bio-fertilizer unit in Coimbatore.

The experiment was conducted in Completely Randomized Block Design with seven treatments and three replications. For each replication, 25 polythene bags were used. Six seeds were sown at $0.5-1.0 \mathrm{~cm}$ depth in black polythene bags of $15 \times 10 \mathrm{~cm}$ size and polybags thickness in 150 gauge. The experiment comprised of seven different seed treatments viz., $\left(\mathrm{CB}_{1}\right)$ control (FYM : Red soil: Sand @ 1:2:1 ratio), $\left(\mathrm{CB}_{2}\right)$ Di ammonium Phosphate (DAP) @ $0.25 \%,\left(\mathrm{CB}_{3}\right)$ Di ammonium Phosphate (DAP) @ $0.5 \%,\left(\mathrm{CB}_{4}\right)$ Potassium dihydrogen orthophosphate $\left(\mathrm{KH}_{2} \mathrm{PO}_{4}\right)$ @ $0.25 \%$, $\left(\mathrm{CB}_{5}\right)$ Potassium dihydrogen orthophosphate $\left(\mathrm{KH}_{2} \mathrm{PO}_{4}\right) @ 0.5$ $\%$, $\left(\mathrm{CB}_{6}\right)$ Pink Pigmented Facultative Methylotrophs (PPFM) @ $1.0 \%$ and $\left(\mathrm{CB}_{7}\right)$ Pink Pigmented Facultative Methylotrophs (PPFM)@2\%. These chemicals and bioinoculants were drenched in the polythene bag at one month after sowing of seedlings.

\section{Results and Discussion}

In the present study, the data represented in Table 1-3 showed that significant effect on catena of observations viz., seedling height and girth, number of leaves, leaf area, shoot and root biomass, leaf nutrient contents of $\mathrm{N}, \mathrm{P}, \mathrm{K}$, leaf chlorophyll and soluble protein content parameters were observed. For this experiment, the observations were taken at seven days interval from one month after germination at 37, 44 and 51 days after sowing.

The highest seedling height (1a) was recorded in $\mathrm{CB}_{5}$ which were $17.30,19.80$ and $25.53 \mathrm{~cm}$ at 37,44 and 51 days after sowing respectively followed by the treatment $\mathrm{CB}_{7}$. The maximum seedling girth (1b) was recorded in $\mathrm{CB}_{7}(2.53,2.82$ and $3.06 \mathrm{~mm}$ at 37,44 and 51 days after sowing respectively) followed by $\mathrm{CB}_{5}$. PPFM had a significant impact on seedling height, seedling girth length (plate 1a), on lines with that $\mathrm{KH}_{2} \mathrm{PO}_{4}$. Madhaiyan et al., 2005, 2006) while studying the influence of PPFM on cotton and sugarcane there was an increased vigour and over all vegetative parameters of the crop since initial stages itself. 
Table.1 Effect of chemicals and bio-inoculants on seedling growth parameters

\begin{tabular}{|c|c|c|c|c|c|c|c|c|c|c|c|c|}
\hline \multirow[t]{2}{*}{ Treatments } & \multicolumn{3}{|c|}{ Seedling height $(\mathrm{cm})$} & \multicolumn{3}{|c|}{$\begin{array}{l}\text { Seedling girth } \\
\qquad(\mathrm{mm})\end{array}$} & \multicolumn{3}{|c|}{ Number of leaves } & \multicolumn{3}{|c|}{ Leaf area $\left(\mathrm{cm}^{2}\right)$} \\
\hline & $\begin{array}{l}37 \\
\text { DAS }\end{array}$ & $\begin{array}{l}44 \\
\text { DAS }\end{array}$ & $\begin{array}{l}51 \\
\text { DAS }\end{array}$ & $\begin{array}{l}37 \\
\text { DAS }\end{array}$ & $\begin{array}{l}44 \\
\text { DAS }\end{array}$ & $\begin{array}{l}51 \\
\text { DAS }\end{array}$ & $\begin{array}{l}37 \\
\text { DAS }\end{array}$ & $\begin{array}{l}44 \\
\text { DAS }\end{array}$ & $\begin{array}{l}51 \\
\text { DAS }\end{array}$ & $\begin{array}{l}37 \\
\text { DAS }\end{array}$ & $\begin{array}{l}44 \\
\text { DAS }\end{array}$ & $\begin{array}{l}51 \\
\text { DAS }\end{array}$ \\
\hline $\mathrm{CB}_{1-}$ - Control & 13.70 & 14.90 & 18.50 & 1.82 & 1.89 & 1.94 & 6.40 & 6.80 & 6.50 & 7.51 & 8.76 & 9.21 \\
\hline $\mathrm{CB}_{2-} \mathrm{DAP} @ 0.25 \%$ & 15.70 & 17.20 & 19.25 & 1.94 & 2.12 & 2.41 & 6.80 & 6.60 & 6.20 & 8.20 & 9.24 & 9.55 \\
\hline $\mathrm{CB}_{3}-\mathrm{DAP} @ 0.5$ & 15.90 & 17.87 & 20.00 & 1.95 & 2.18 & 2.48 & 6.60 & 6.87 & 6.63 & 8.80 & 9.97 & 10.32 \\
\hline $\mathrm{CB}_{4}-\mathrm{KH}_{2} \mathrm{PO}_{4} @ 0.25 \%$ & 15.80 & 19.40 & 22.70 & 2.41 & 2.46 & 2.58 & 6.30 & 7.20 & 6.75 & 9.06 & 10.20 & 11.76 \\
\hline $\mathrm{CB}_{5}-\mathrm{KH}_{2} \mathrm{PO}_{4} @ 0.5 \%$ & 17.30 & 19.80 & 25.53 & 2.49 & 2.71 & 2.78 & 6.80 & 7.01 & 7.00 & 9.25 & 11.60 & 12.20 \\
\hline 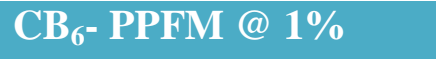 & 16.40 & 19.40 & 22.55 & 2.28 & 2.40 & 2.44 & 6.50 & 6.80 & 6.00 & 9.21 & 11.64 & 12.09 \\
\hline $\mathrm{CB}_{7^{-}}$PPFM @ 2\% & 17.20 & 19.60 & 23.25 & 2.53 & 2.82 & 3.06 & 6.40 & 6.50 & 6.50 & 10.30 & 11.80 & 12.68 \\
\hline Mean & 16.0 & 18.21 & 21.68 & 2.27 & 2.56 & 2.68 & 6.54 & 6.83 & 6.51 & 8.91 & 10.46 & 11.11 \\
\hline SEd & 0.31 & 0.29 & 0.33 & 0.05 & 0.02 & 0.04 & 0.11 & 0.12 & 0.05 & 0.11 & 0.05 & 0.17 \\
\hline CD $(0.05)$ & 0.68 & 0.64 & 0.73 & 0.11 & 0.06 & 0.09 & 0.24 & 0.27 & 0.12 & 0.25 & 0.12 & 0.38 \\
\hline CV\% & 2.39 & 2.00 & 1.89 & 2.75 & 1.33 & 2.35 & 2.07 & 2.24 & 1.11 & 1.63 & 0.66 & 1.94 \\
\hline Significance & $*$ & $*$ & $* *$ & $* *$ & $* *$ & $* *$ & NS & NS & NS & $* *$ & $* *$ & $* *$ \\
\hline
\end{tabular}

(DAP- Di ammonium Phosphate; $\mathrm{KH}_{2} \mathrm{PO}_{4}$ - Potassium dihydrogen orthophosphate; PPFM- Pink Pigmented Facultative Methylotrophs) 
Table.2 Effect of chemicals and bio-inoculants on shoot and root growth parameter

\begin{tabular}{|c|c|c|c|c|c|c|}
\hline Treatments & $\begin{array}{l}\text { Shoot } \\
\text { length } \\
(\mathrm{cm})\end{array}$ & $\begin{array}{c}\text { Root } \\
\text { length } \\
\text { (cm) }\end{array}$ & $\begin{array}{l}\text { Fresh } \\
\text { weight of } \\
\text { the shoot } \\
\text { (g) }\end{array}$ & $\begin{array}{c}\text { Fresh } \\
\text { weight } \\
\text { of the } \\
\text { root }(\mathrm{g})\end{array}$ & $\begin{array}{c}\text { Dry } \\
\text { weight } \\
\text { of the } \\
\text { shoot } \\
\text { (g) }\end{array}$ & $\begin{array}{c}\text { Dry } \\
\text { weight } \\
\text { of the } \\
\text { root } \\
\text { (g) }\end{array}$ \\
\hline $\mathrm{CB}_{1}$ - Control & 18.68 & 10.25 & 0.84 & 0.08 & 0.05 & 0.03 \\
\hline $\mathrm{CB}_{2-}$ DAP@ $0.25 \%$ & 22.70 & 12.50 & 1.21 & 0.11 & 0.10 & 0.04 \\
\hline $\mathrm{CB}_{3^{-}}$DAP @ 0.5 & 22.55 & 13.25 & 1.58 & 0.11 & 0.13 & 0.03 \\
\hline $\begin{array}{lll}\mathrm{CB}_{4}- & \mathrm{KH}_{2} \mathrm{PO}_{4} & @ \\
\mathbf{0 . 2 5 \%} & & \\
\end{array}$ & 23.60 & 12.75 & 1.18 & 0.12 & 0.16 & 0.06 \\
\hline $\begin{array}{l}\mathrm{CB}_{5}-\mathrm{KH}_{2} \mathrm{PO}_{4} @ \\
0.5 \%\end{array}$ & 26.75 & 16.30 & 1.73 & 0.15 & 0.21 & 0.09 \\
\hline $\mathrm{CB}_{6-}$ PPFM @ 1\% & 23.25 & 13.25 & 1.48 & 0.13 & 0.16 & 0.06 \\
\hline $\mathrm{CB}_{7}$ - PPFM @ 2\% & 25.28 & 14.25 & 1.66 & 0.14 & 0.19 & 0.07 \\
\hline Mean & 23.30 & 13.22 & 1.25 & 0.114 & 0.142 & 0.034 \\
\hline SEd & 0.52 & 0.25 & 0.03 & 0.001 & 0.003 & 0.001 \\
\hline CD (0.05) & 1.13 & 0.54 & 0.07 & 0.002 & 0.008 & 0.003 \\
\hline CV\% & 2.73 & 2.32 & 3.38 & 1.126 & 3.008 & 2.109 \\
\hline Significance & $* *$ & $* *$ & $*$ & $* *$ & $* *$ & $*$ \\
\hline
\end{tabular}

(DAP- Di ammonium Phosphate; $\mathrm{KH}_{2} \mathrm{PO}_{4^{-}}$Potassium dihydrogen orthophosphate; PPFM- Pink Pigmented Facultative Methylotrophs)

Table.3 Effect of chemicals and bio-inoculants on leaf nutrient contents of N, P, K, chlorophyll and soluble protein contents

\begin{tabular}{|c|c|c|c|c|c|}
\hline Treatments & $\begin{array}{c}\text { Chlorophyll } \\
\text { content } \\
\left(\mathrm{mg} \mathrm{g}^{-1}\right)\end{array}$ & $\begin{array}{c}\text { Leaf soluble } \\
\text { protein }\left(\mathrm{mg} \mathrm{g}^{-1}\right)\end{array}$ & $\begin{array}{c}\mathbf{N} \\
(\%)\end{array}$ & $\begin{array}{c}\mathbf{P} \\
(\%)\end{array}$ & $\underset{(\%)}{K}$ \\
\hline $\mathrm{CB}_{1}$ - Control & 1.96 & 43.94 & 0.99 & 0.62 & 1.27 \\
\hline $\mathrm{CB}_{2-}$ DAP@0.25\% & 2.21 & 45.59 & 1.13 & 0.69 & 1.34 \\
\hline $\mathrm{CB}_{3}-\mathrm{DAP} @ 0.5 \%$ & 2.17 & 51.02 & 1.02 & 0.74 & 1.42 \\
\hline $\mathrm{CB}_{4}-\mathrm{KH}_{2} \mathrm{PO}_{4} @ 0.25 \%$ & 2.29 & 50.02 & 1.17 & 0.82 & 2.14 \\
\hline $\mathrm{CB}_{5}-\mathrm{KH}_{2} \mathrm{PO}_{4} @ 0.5 \%$ & 2.32 & 52.18 & 1.38 & 0.89 & 2.72 \\
\hline $\mathrm{CB}_{6}-\mathrm{PPFM} @ 1 \%$ & 2.24 & 50.82 & 1.14 & 0.75 & 2.01 \\
\hline $\mathrm{CB}_{7^{-}}$PPFM @ 2\% & 2.41 & 53.37 & 1.26 & 0.84 & 2.67 \\
\hline Mean & 2.22 & 48.99 & 1.16 & 0.76 & 1.94 \\
\hline SEd & 0.01 & 0.73 & 0.01 & 0.01 & 0.03 \\
\hline CD (0.05) & 0.03 & 1.59 & 0.02 & 0.02 & 0.07 \\
\hline CV\% & 0.96 & 1.83 & 1.18 & 1.90 & 2.06 \\
\hline Significance & $*$ & $* *$ & * & $*$ & $*$ \\
\hline
\end{tabular}

(DAP- Di ammonium Phosphate; $\mathrm{KH}_{2} \mathrm{PO}_{4^{-}}$Potassium dihydrogen orthophosphate; PPFM- Pink Pigmented Facultative Methylotrophs) 

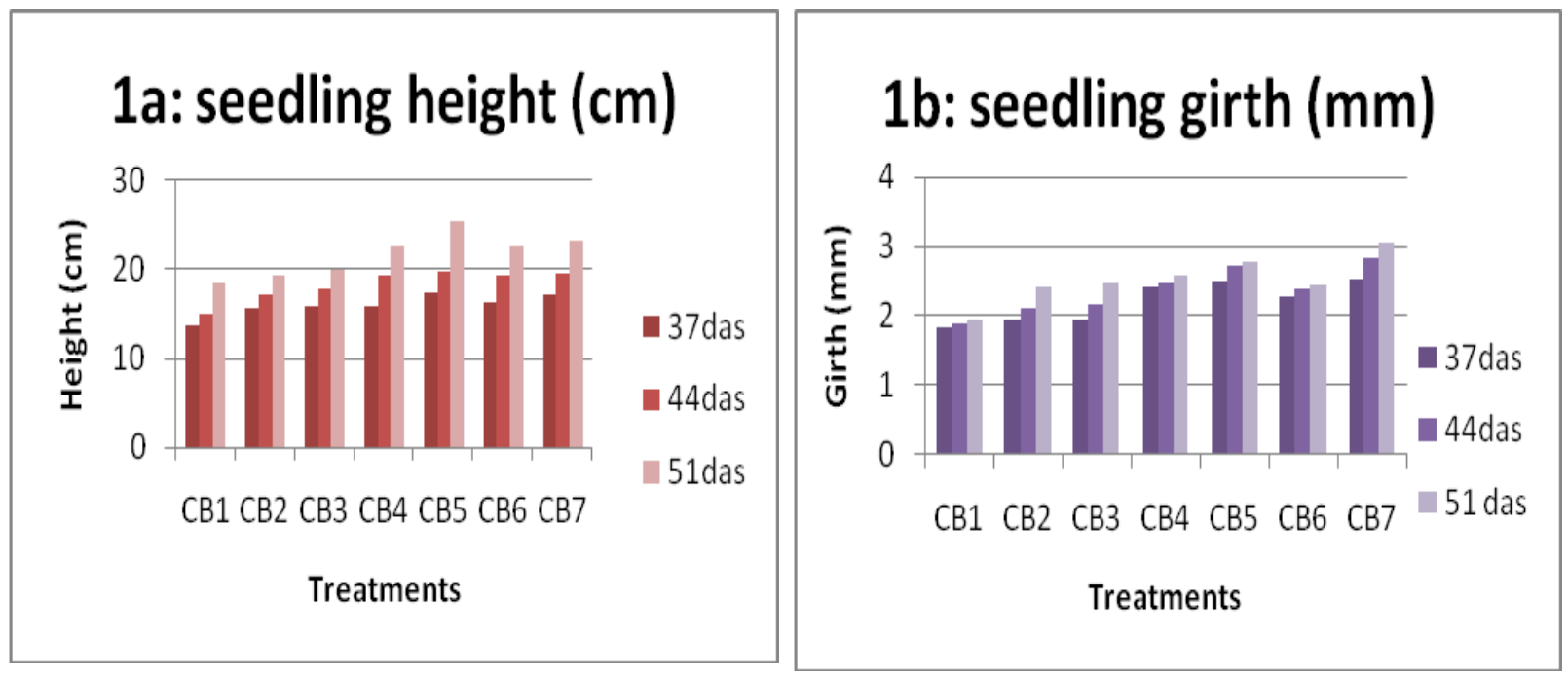

Plate I a: Effect of chemicals and bioinoculants on seedling growth and vigour

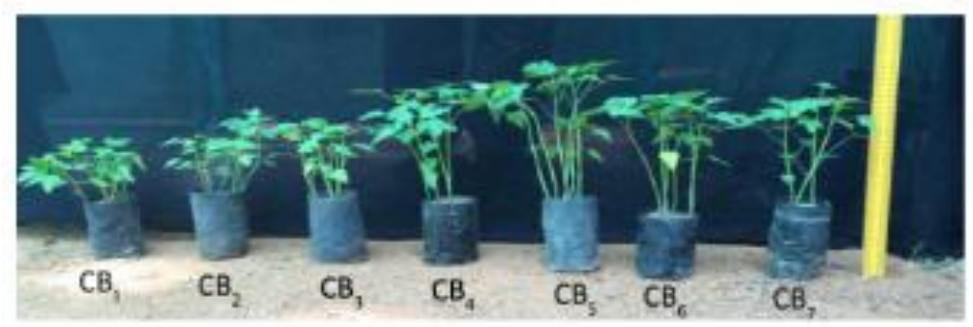

37 DAS

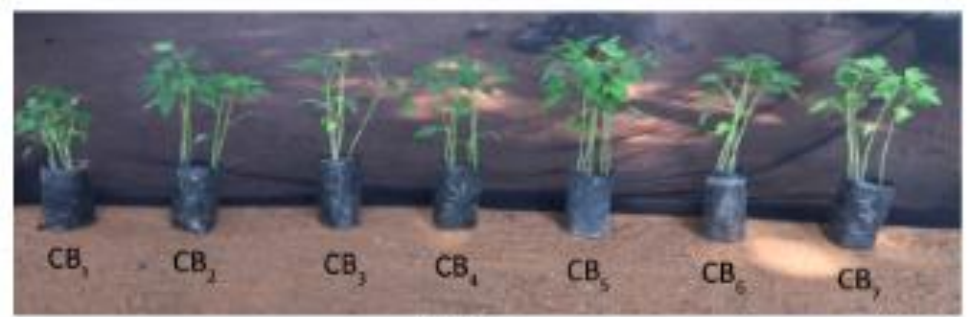

44 DAS

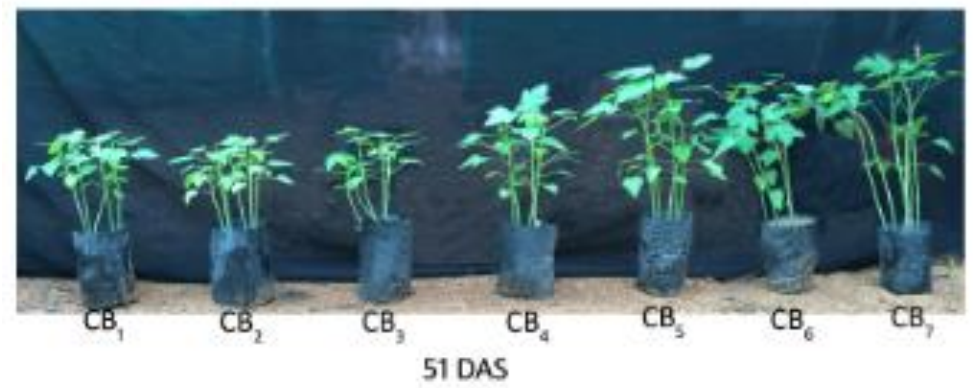

$\mathrm{CB}_{1}$ : Control; $\mathrm{CB}_{2}$ : DAP @0.25\%; $\mathrm{CB}_{2}: \mathrm{DAP} @ 0.5 \%$;

$\mathrm{CB}_{3}: \mathrm{KH}_{2} \mathrm{PO}_{4}$ @ $0.25 \% ; \mathrm{CB}_{4}: \mathrm{KH}_{2} \mathrm{PO}_{4}$ @ $0.50 \% ; \mathrm{CB}_{5}:$ PPFM @ $1 \%$

$\mathrm{CB}_{\mathrm{r}}: \mathrm{PPFM} 2 \%$ 
Plate I b: Effect of chemicals and bioinoculants on root biomass

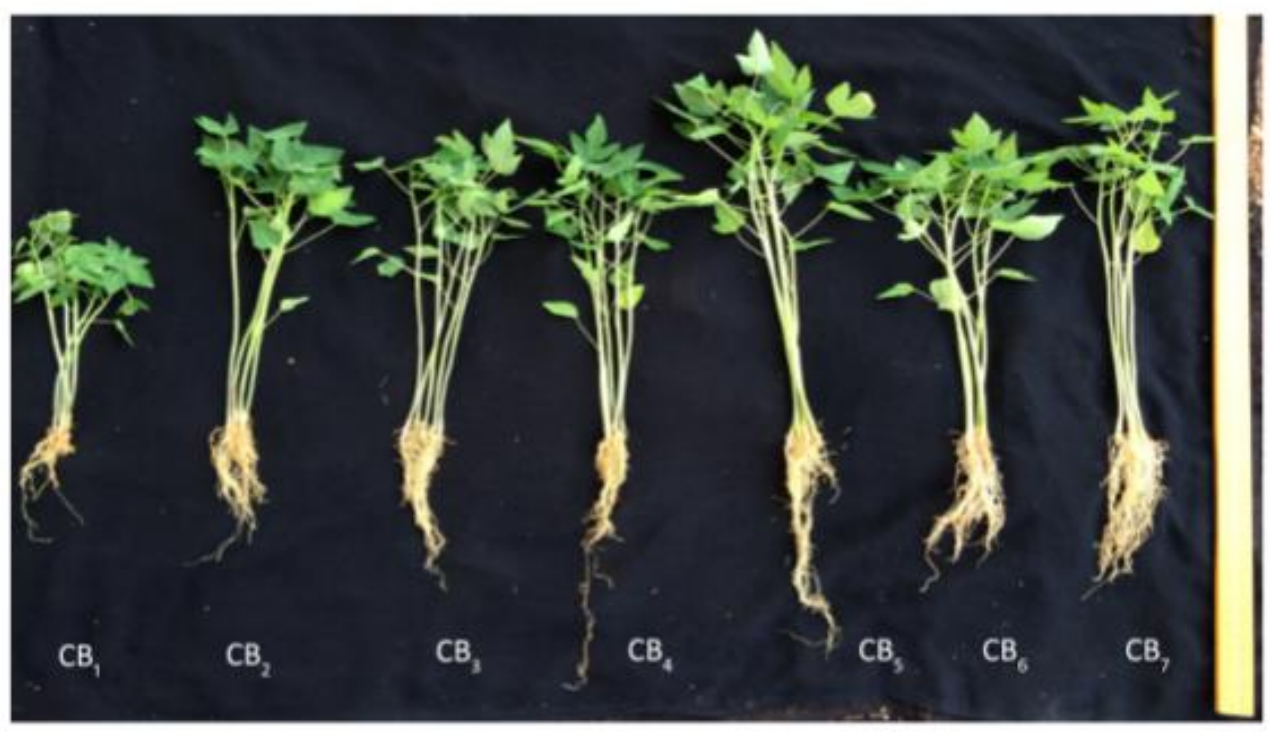

$\mathrm{CB}_{1}:$ Control; $\mathrm{CB}$ : DAP @0.25\%; CB,: DAP@ $0.5 \%$;

$\mathrm{CB}_{3}: \mathrm{KH}_{2} \mathrm{PO} \mathrm{O}_{4} @ 0.25 \%$; $\mathrm{CB}_{4}: \mathrm{KH}_{2} \mathrm{PO}_{4} @ 0.50 \%$; $\mathrm{CB}_{5}:$ PPFM @ $1 \%$ $\mathrm{CB}_{\text {; }}$ PPFM@ $2 \%$

(DAP- Di ammonium Phosphate; $\mathrm{KH}_{2} \mathrm{PO}_{4^{-}}$Potassium dihydrogen orthophosphate; PPFM- Pink Pigmented Facultative Methylotrophs)

PPFM trends to form a strong, or symbiotic to loose, or epiphytic kind of association with the host plant and potentially dominate the phyllosphere bacterial population. In addition to this ability, they also colonize the rhizosphere of plant species. PPFM also increases the availability of growth regulators such as IAA and cytokinins (Omer et al., 2004; Madhaiyan et al., 2005, 2006 and Senthilkumar et al., 2009). The results obtained also support the beneficial role of PPFM in imparting vigour in papaya seedlings.

The leaf area was the highest in $\mathrm{CB}_{7}$ which recorded 10.30, 11.80 and $12.68 \mathrm{~cm}^{2}$ leaf area at 37, 44 and 51 days after sowing respectively followed by $\mathrm{CB}_{5}$.

The shoot length (plate 1b), fresh and dry weight of shoot was the highest in $\mathrm{CB}_{5}$ which recorded $26.75 \mathrm{~cm}, 1.73 \mathrm{~g}$ and $0.21 \mathrm{~g}$ respectively followed by $\mathrm{CB}_{7}$ treatment which recorded $25.28 \mathrm{~cm}, 1.66 \mathrm{~g}$ and $0.19 \mathrm{~g}$ respectively. The root length(plate $1 \mathrm{~b}$ ), fresh and dry weight of the root was the highest in $\mathrm{CB}_{5}$ which recorded $16.30 \mathrm{~cm}, 0.15 \mathrm{~g}$ and 0.09 respectively followed by $\mathrm{CB}_{7}$ treatment which recorded $14.25 \mathrm{~cm}, \quad 0.14 \mathrm{~g}$ and 0.07 respectively. Might be $\mathrm{K}$ plays a central role in maintaining photosynthesis and related processes by maintaining the $\mathrm{K}$ : Na balance in the plants Cakmak (2005). The same treatment also recorded the highest leaf NPK, chlorophyll and soluble protein content. Sahib et al., (2014) concluded that okra seeds primed for 4 hours at two temperatures (20 and $30^{\circ} \mathrm{C}$ ) in priming media with $\mathrm{KH}_{2} \mathrm{PO}_{4} @$ $3 \%$ improved seed germination percentage, germination speed index (GSI) and seedling vigour index (SVI). Hence, it might be showed the effect of chemicals and bioinoculants on nitrogen, phosphorous and potassium content were found significantly different among treatments. The highest nitrogen, phosphorous and potassium contents were recorded in $\mathrm{CB}_{5}(1.38 \%, 0.89 \%$ and $2.72 \%$ respectively) followed by $1.12 \%$, $0.84 \%$ and $2.67 \%$ in $\mathrm{CB}_{7}$ at $37,44,51 \mathrm{DAS}$ respectively. 
This experiment pertains to the effect of Potassium dihydrogen orthophosphate $\left(\mathrm{KH}_{2} \mathrm{PO}_{4}\right)$, DAP and PPFM (bio-inoculant) on seed germination, seedling vigour. Among the treatments, application of $\mathrm{KH}_{2} \mathrm{PO}_{4} @ 0.5 \%$ to the one month old seedlings in the nursery recorded the highest seedling growth characters, followed by PPFM $2.0 \%$. Pertaining to seedling girth, seedling height both the treatments were significantly on same yardstick statistically. It might be due to the Pink pigmented facultative methylotrophs (PPFMs) of the genus Methylobacterium are commonly found in association with plants and have been hypothesized potentially to dominate the phyllosphere bacterial population (Corpe and Raheem, 1989). The consistent success of Methylobacterium strains in colonizing the phyllosphere is probably due to their ability to utilize methanol as a carbon and energy source, although the surfaces of plants are also covered with soluble carbohydrates, amino acids, organic and phenolic acids, terpenes, and alkaloids (Corpe and Raheem, 1989; Fiala et al., 1990). The seedling weight and shoot length of Nicotiana tabacum, Lycopersicon esculentum, Sinapis alba, and Fragaria vesca increased significantly in the presence of the pink-pigmented facultative methylotroph (PPFM) strain Methylobacteriumextorquens ME4 (Abanda et al., 2006).

The effect of Chemicals and bio-inoculants application on one month old seedlings showed the best results with $\mathrm{KH}_{2} \mathrm{PO}_{4} @ 0.5$ $\%$ followed by PPFM @ $2.0 \%$ and can be recommended for improving seedling growth and vigour of TNAU Papaya CO.8.

\section{References}

Abanda N. D., M. Musch, J. Tschiersch, M. Boettner and W. Schwab. 2006. Molecular interaction between Methylobacterium extorquens and seedlings: growth promotion, methanol consumption, and localization of the methanol emission site. J. Exp. Bot., 57(15): 4025-4032.

Anonymous 2015.National Horticulture Board Database. 2015-16. www.nhb. gov.in

Arumuganathan, K. and E. D. Earle. 1991. Estimation of nuclear DNA content of plants by flow cytometry. Plant molecular biology reporter. 9(3): 229241.

Barche, S., K.S. Kirad and D.B. Singh. 2010. Response of seed treatment on germination, growth, survivability and economics of different cultivars of papaya. Acta Horticulturae., (851): 279284.

Bennett M. D. and I.J. Leitch. 2005. Nuclear DNA amounts in angiosperms: progress, problems and prospects. Annals of Botany., 95:45-90.

Cakmak, I. 2005. The role of potassium in alleviating detrimental effects of abiotic stresses. J. Plant Nutr. Soil Sci., 168: 521-530.

Chattopadhyay, R.R. 2003. Possible mechanism of hepatoprotective activity of Azadirachta indica leaf extract. Part II. J. Ethnopharmacology., 89: 217-219.

Corpe, W. A., and S. Raheem, (1989).Ecology of the methylotrophic bacteria on living leaf surfaces. FEMS Microbiology Letters., 62(4): 243-249.

Fiala, V., C. Glad, M. Martin, E. Jolivet and S. Derridj. 1990. Occurrence of soluble carbohydrates on the phylloplane of maize (Zea mays L.) variations in relation to leaf heterogeneity and position on the plant. New Phytologist., 115(4): 609-615.

Kadam, N. 1992.Effect of seed treatment with chemical on germination of papaya seed cv. Washington. Proc. Nat. Sem. Prod. Utiliz.Papaya.6-7 March, 1992, TNAU, Coimbatore, pp. 26. 
Madhaiyan, M., B.V.Suresh Reddy, R. Anandham, M. Senthilkumar, S. Poonguzhali, SP. Sundaram and T.M. Sa. 2006. Plant growth promoting Methylobacterium induces defense responses in groundnut (Arachis hypogaea L.) compared to rot pathogens. Curr. Microbiol. 53: 270276.

Madhaiyan, M., S. Poonguzhali, H.S. Lee, K. Hari, S.P. Sundaram and T. M. Sa. 2005. Pink-pigmented facultative methylotrophic bacteria accelerate germination, growth and yield of sugarcane clone Co86032 (Saccharum officinarum L.). Biol. fertility of soils. 41(5): 350-358.
Omer ZS, R. Tombolini and B. Gerhardson. 2004. Plant colonization by pinkpigmented facultative methylotrophic bacteria (PPFMs). FEMS Microbiology Ecology. 46: 319-326.

Sahib, M.M., N. A. Hamzah and H.J. Hussein. 2014. Effect of seed priming by $\mathrm{KH} 2 \mathrm{PO} 4$ and different temperature on seeds germination behavior of okra (Abelmoschus esculentus L.).

Senthilkumar, M., M. Madhaiyan, SP. Sundaram and S. Kannaiyan. 2009. Intercellular colonization and growth promoting effects of Methylobacterium sp. With plant-growth regulators on rice (Oryza sativa L. cv Co-43). Microbilogical Research., 164: 92-104.

\section{How to cite this article:}

Donaka Dayeswari, Jone Auxcilia, K. Malarkodi and Vijayakumar, R.M. 2018. Effect of Chemicals and Bio-Inoculants on Seedling Growth and Vigour of TNAU Papaya CO.8 (Carica papaya L.). Int.J.Curr.Microbiol.App.Sci. 7(03): 3007-3014. doi: https://doi.org/10.20546/ijcmas.2018.703.348 